\title{
Toxins A and B from Clostridium difficile Differ with Respect to Enzymatic Potencies, Cellular Substrate Specificities, and Surface Binding to Cultured Cells
}

\author{
Esteban Chaves-Olarte, ${ }^{\star}$ Manfred Weidmann, ${ }^{\ddagger}$ Christoph von Eichel-Streiber, ${ }^{\ddagger}$ and Monica Thelestam* \\ * Microbiology and Tumorbiology Center (MTC), Karolinska institutet, S-171 77 Stockholm, Sweden, and ${ }^{*}$ Verfügungsgebaude für \\ Forschung und Entwicklung, Institut für Medizinische Mikrobiologie und Hygiene, Johannes Gutenberg-Universität Mainz, 55101 \\ Mainz, Germany
}

\begin{abstract}
Clostridium difficile toxins A and B together are responsible for the symptoms of pseudomembranous colitis. Both toxins intoxicate cultured cells by the same mechanism but they differ in cytotoxic potency, toxin B being generally 1,000 times more potent than toxin A. Don and T84 cells were used to determine differences in the intoxication process exerted by both toxins. Three main differences were identified: $(a)$ the specific binding of radiolabeled toxins to the cell surfaces correlated with the cytotoxic potency, $(b)$ toxin B was found to have a 100 -fold higher enzymatic activity than toxin $\mathrm{A}$, and $(c)$ toxin A was found to modify an additional substrate, Rap. The relative contribution of $(a)$ and $(b)$ to the difference in cytotoxic potency was determined by microinjection of the toxins. The differing enzymatic activities turned out to be the main determinant of the difference in cytotoxic potency, whereas the difference in binding contributes to a lesser degree. These findings are discussed in the context of the pathophysiological role of the toxins. (J. Clin. Invest. 1997. 100:1734-1741.) Key words: glucosyltransferase • Ras proteins • pseudomembranous enterocolitis • cultured tumor cells $\cdot$ lung fibroblasts
\end{abstract}

\section{Introduction}

Clostridium difficile produces two toxins, A and B (TcdA, $\mathrm{TcdB}),{ }^{1}$ which together are responsible for the symptoms in pseudomembranous colitis induced by this bacterium. TcdA and TcdB share molecular characteristics reflected by a high homology of their sequences (63\% at the amino acid level) and their similar sizes ( $308 \mathrm{kD}$ for TcdA and 269 for TcdB) (1). The molecules are structurally organized in a similar way, with at least three recognizable domains: $(a)$ the amino-terminal

Address correspondence to Monica Thelestam, Ph.D., Microbiology and Tumorbiology Center (MTC), Karolinska institutet, Box 280, S-171 77 Stockholm, Sweden. Phone 46-8-728-71-62; FAX: 46-8-3315-47; E-mail: monica.thelestam@mtc.ki.se

Received for publication 19 March 1997 and accepted in revised form 8 July 1997.

1. Abbreviations used in this paper: CPE, cytopathic effect; Don, diploid Chinese hamster lung; TCD, tissue culture dose; TcdA, Clostridium difficile toxin $\mathrm{A}$; TcdB, Clostridium difficile toxin $\mathrm{B}$; UDP-Glc, uridine diphosphoglucose.

J. Clin. Invest.

(C) The American Society for Clinical Investigation, Inc. 0021-9738/97/10/1734/08 \$2.00

Volume 100, Number 7, October 1997, 1734-1741

http://www.jci.org third, which contains the active site (2), (b) the carboxy-terminal domain, which contains repeating units responsible for binding the toxin to receptors on the cell surface $(3,4)$, and $(c)$ a hydrophobic domain thought to be important for the translocation process (1). This molecular organization appears common for several so-called large clostridial cytotoxins (1), such as the Clostridium sordellii lethal toxin (TcsL), which crossreacts immunologically with TcdB (5).

The molecular mode of action of the $C$. difficile toxins has been clarified recently. Both toxins were identified as uridine diphosphoglucose (UDP-Glc) hydrolases and glucosyltransferases $(6,7)$. In toxin-treated cells, a glucose moiety is liberated from UDP-Glc and attached covalently to a conserved amino acid in the cellular target molecules. For both toxins, these targets were reported to be the small GTP-binding proteins Rho, Rac, and Cdc42 within the Rho subfamily of Rasrelated GTPases (6-8). Upon glucosylation, the GTPases are inactivated. This leads to a collapse of the actin cytoskeleton (9) with a characteristic actinomorphic cytopathic effect (CPE) and cell death as consequences. Thus, both TcdA and TcdB act intracellularly as cytotoxins, consistent with our previous reports on their internalization by endocytosis after binding to the cell surface $(10,11)$. The trisaccharide Gal $\alpha 3$ Gal $\beta 4$ GlcNAc $\beta$ appears to be the minimum receptor structure required for binding TcdA (12), whereas no receptor structure for TcdB has yet been identified.

TcdA and TcdB differ significantly with respect to enterotoxicity and cytotoxic potency. TcdA, when administered intragastrically, causes hemorrhagic fluid secretion, mucosal inflammation, necrosis of the intestinal tissue, and death of the animal (13). In contrast, TcdB, given intragastrically, has no effect on the intestine (13). Thus, TcdA is traditionally defined as the enterotoxin, but like TcdB it is also cytotoxic to cultured cells according to the basic mode of action described above. However, the two toxins exhibit a remarkable difference in cytotoxic potencies, TcdB being generally 500-1,000 times more potent than TcdA $(1,8,14)$. Some studies have suggested that this difference in cytotoxic potency could depend on the density of toxin-specific receptors on the surface of cells. For instance, teratocarcinoma cell lines which abundantly express the TcdA-binding carbohydrate were reported to be unusually sensitive to the cytotoxicity caused by this toxin (15). However, these teratocarcinoma cells were still more sensitive to TcdB than to TcdA, and the cell surface binding of the toxins was not studied.

In conclusion, although TcdA and TcdB have the same molecular mode of action, they differ considerably with respect to biological actions, and the reason(s) for this is not clear. The purpose of this work was to clarify why TcdA and TcdB differ with respect to cytotoxic potencies. The interactions of both toxins with cells, in terms of surface binding and internalization, enzymatic activity, and ensuing CPE were investigated, 
and a 100-fold difference in enzymatic activity was found to be the main determinant of the differing cytotoxic potencies.

\section{Methods}

Materials. TcdA, TcdB, and TcsL were purified as described earlier $(16,17)$. UDP- $\left[{ }^{14} \mathrm{C}\right] \mathrm{Glc}$ (specific activity $318 \mathrm{mCi} / \mathrm{mmol}$ ) was obtained from DuPont-NEN (Dreieich, Germany). $N$-succinimidyl $\left[2,3-{ }^{3} \mathrm{H}\right]$ propionate (specific activity $96 \mathrm{Ci} / \mathrm{mmol}$ ) and $N$-succinimidyl 3-(4-hydroxy,5-[125I] iodophenyl) propionate (specific activity 2,000 Ci/mmol) were obtained from Amersham Life Science (Buckinghamshire, UK). Goat antisera to TcdA and TcdB were a generous gift from Dr. D.M. Lyerly, Virginia Polytechnic Institute, Blacksburg, VA. Recombinant proteins Rho, Rac, Cdc42, and Rap were kindly provided by Dr. P. Boquet, INSERM, Nice, France. All other reagents were of analytical grade and obtained from local commercial sources.

Protein determination. Protein concentration in toxin preparations and in cell lysates was determined using a protein assay kit (BioRad Laboratories, Hercules, CA) according to the manufacturer's instructions. BSA was used as standard. SDS-PAGE analysis of toxin preparations showed one single band of the expected size.

Cell culture and preparation of lysates. Diploid Chinese hamster lung fibroblasts (Don cells, CCL-16; American Type Culture Collection, Rockville, MD) were cultivated in Eagle's MEM supplemented with $10 \%$ FBS, $5 \mathrm{mM}$ L-glutamine, penicillin $(100 \mathrm{U} / \mathrm{ml})$, and streptomycin $(100 \mu \mathrm{g} / \mathrm{ml})$ (GIBCO BRL, Gaithersburg, MD). Human colon carcinoma T84 cells (CCL-248; American Type Culture Collection) were cultivated in a 1:1 mixture of Ham's F12 medium and DME supplemented with 5\% FBS plus L-glutamine and antibiotics as above. Both cell lines were incubated at $37^{\circ} \mathrm{C}$ in a humid atmosphere containing $5 \% \mathrm{CO}_{2}$. Toxin titrations were performed using cells cultivated to $90 \%$ confluency in 96 -well plates. The initial concentration tested was $5 \mu \mathrm{g} / \mathrm{ml}$, and subsequent $1 / 10$ dilutions were made. Cytotoxicity was scored microscopically, and the results were expressed as the percentage of affected cells.

Cell lysates were prepared as described previously (18). Briefly, confluent cells grown in $75-\mathrm{cm}^{2}$ flasks were rinsed, mechanically removed, and washed twice with ice-cold HBSS. Cell pellets were resuspended in $200 \mu \mathrm{l}$ lysis buffer $(50 \mathrm{mM}$ triethanolamine, $150 \mathrm{mM}$ $\mathrm{KCl}, 2 \mathrm{mM} \mathrm{MgCl} 2,0.5 \mathrm{mM}$ GDP, $1 \mathrm{mM}$ DTT, $0.1 \mathrm{mM}$ PMSF, $10 \mu \mathrm{g} /$ $\mathrm{ml}$ leupeptin, $\mathrm{pH} 7.8$ ) and sonicated five times for $5 \mathrm{~s}$. After centrifugation $(14,000 \mathrm{~g}, 3 \mathrm{~min})$, the supernatant was used as postnuclear cell lysate.

UDP-Glc hydrolase activity. Toxins $(100 \mu \mathrm{g} / \mathrm{ml}$ in lysis buffer $)$ were incubated with UDP- $\left[{ }^{14} \mathrm{C}\right] \mathrm{Glc}(60 \mu \mathrm{M})$ at $37^{\circ} \mathrm{C}$ for the indicated times. The reaction was terminated by heating the samples at $95^{\circ} \mathrm{C}$ for $3 \mathrm{~min}$. Uncleaved UDP- $\left[{ }^{14} \mathrm{C}\right] \mathrm{Glc}$ was separated from hydrolysis products by adsorption onto activated charcoal (19) (20 mg/ml in PBS). The activated charcoal was washed with PBS, the adsorbed UDP- $\left[{ }^{14} \mathrm{C}\right] \mathrm{Glc}$ was eluted with $50 \mu \mathrm{l} 10 \%$ acetic acid, and radioactivity was determined by scintillation counting in $5 \mathrm{ml}$ of OptiPhase (EG\&G Wallac, Milton Keynes, UK).

Glucosyltransferase activity. $5 \mu \mathrm{UDP}-\left[{ }^{14} \mathrm{C}\right] \mathrm{Glc}$ dissolved in ethanol was dried under vacuum, and $10 \mu \mathrm{l}$ cell lysate $(5 \mathrm{mg}$ protein $/ \mathrm{ml})$ or recombinant Rho, Rac, Cdc42, or Rap1 or -2 (1-3 $\mu \mathrm{g})$ were added. The final UDP- $\left[{ }^{14} \mathrm{C}\right] \mathrm{Glc}$ concentration was $30 \mu \mathrm{M}$. These mixtures were incubated with $\mathrm{TcdA}$ or $\mathrm{TcdB}$ at the indicated concentrations for $1 \mathrm{~h}$ at $37^{\circ} \mathrm{C}$. The reaction was terminated by heating at $95^{\circ} \mathrm{C}$ in sample buffer (20). Proteins were separated by $12.5 \%$ SDS-PAGE. Radiolabeled bands were detected by PhosphorImager analysis (Molecular Dynamics, Sunnyvale, CA). The intensity of the bands was calculated using ImageQuant software (Molecular Dynamics). With cell lysates, the result was expressed as percentage of the labeling obtained with TcdB $(50 \mu \mathrm{g} / \mathrm{ml})$. With recombinant proteins, the result was expressed as percentage of the labeling obtained with either TcdB $(500 \mu \mathrm{g} / \mathrm{ml})$ or TcsL $(500 \mu \mathrm{g} / \mathrm{ml})$ as indicated.

Microinjection experiments. Don cells were cultivated on 13-mm slides for $48 \mathrm{~h}$. Toxin-specific antiserum (1/100) was added to the medium to neutralize any toxin molecules leaking from the injection needle. Semiconfluent cells were microinjected (using an Eppendorf microinjector) with the indicated concentration of either TcdA or TcdB diluted in PBS containing 2\% fluorescein dextran (to localize microinjected cells). After microinjection, cells were incubated for $2 \mathrm{~h}$ at $37^{\circ} \mathrm{C}$, washed with PBS, and fixed with $3.7 \%$ paraformaldehyde. Microinjected cells were localized by fluorescence microscopy, and CPE was determined by phase contrast microscopy. Three different fields were analyzed per experiment, and the fraction of affected cells was expressed as percentage of microinjected (fluorescent) cells.

Radiolabeling of TcdA and TcdB. $50 \mu \mathrm{l}$ of $N$-succinimidyl [2,3${ }^{3} \mathrm{H}$ )propionate dissolved in toluene or $N$-succinimidyl 3-(4-hydroxy,5$\left[{ }^{125} \mathrm{I}\right]$ iodophenyl) propionate dissolved in dry benzene was dried under a nitrogen stream, and TcdA or TcdB ( $45 \mu \mathrm{g}$ for ${ }^{3} \mathrm{H}$-labeling and $20 \mu \mathrm{g}$ for ${ }^{125}$ I-labeling) dissolved in $50 \mu \mathrm{l} 0.1 \mathrm{M}$ borate, $\mathrm{pH} 8.5$, was added. The mixture was incubated $18 \mathrm{~h}$ for Hydrogen-3 labeling and $2 \mathrm{~h}$ for Iodine- 125 labeling at $0^{\circ} \mathrm{C}$. The reaction was terminated by addition of $0.2 \mathrm{M}$ glycine in $0.1 \mathrm{M}$ borate and $0.05 \mathrm{M}$ sodium phosphate, $\mathrm{pH}$ 7.5. The labeled toxin was dialyzed against $0.05 \mathrm{M}$ sodium phosphate to remove the nonbound reagent. After labeling with either reagent, both toxins retained $>95 \%$ activity as assessed by cytotoxicity titrations.

Binding and internalization of ${ }^{3} H-T c d A$ and ${ }^{3} H-T c d B$. For internalization studies, ${ }^{3} \mathrm{H}$-TcdA or ${ }^{3} \mathrm{H}-\mathrm{TcdB}(1 \mu \mathrm{g} / \mathrm{ml})$ was added to confluent Don or T84 cells grown in 24-well plates. After $2 \mathrm{~h}$ incubation at $37^{\circ} \mathrm{C}$, cells were washed three times with PBS and lysed with $200 \mu \mathrm{l}$ $1 \%$ Nonidet P-40. Radioactivity was measured by liquid scintillation counting. Cell surface binding was determined by adding ice-cold ${ }^{3} \mathrm{H}$-labeled toxins $(1 \mu \mathrm{g} / \mathrm{ml})$ to precooled $\left(15 \mathrm{~min}\right.$ at $\left.4^{\circ} \mathrm{C}\right)$ Don or $\mathrm{T} 84$ cells grown in 24-well plates. After $2 \mathrm{~h}$ incubation at $4^{\circ} \mathrm{C}$, cells were washed three times with PBS, lysed with $200 \mu 11 \%$ Nonidet P-40, and radioactivity was measured by liquid scintillation counting.

Specific binding of ${ }^{125} I-T c d A$ and ${ }^{125} I-T c d B$. Specific binding and saturation were determined following the classical procedure described by Middlebrook (21). Total binding was determined by addition of ice-cold ${ }^{125} \mathrm{I}-\mathrm{TcdA}$ or ${ }^{125} \mathrm{I}-\mathrm{TcdB}$ at the indicated concentrations to precooled $\left(15 \mathrm{~min}\right.$ at $\left.4^{\circ} \mathrm{C}\right)$ Don or T84 cells grown in 96-well plates. After $2 \mathrm{~h}$ incubation at $4^{\circ} \mathrm{C}$, cells were washed three times with PBS, lysed with $50 \mu \mathrm{l} 1 \%$ Nonidet P-40, and radioactivity was counted in an automatic gamma counter. Nonspecific binding was determined following the same protocol but in the presence of a 100-fold excess of nonlabeled toxin. Specific binding was calculated by substraction of nonspecific binding from total binding. No crossreactivity was detected between TcdA and TcdB (i.e., ${ }^{125}$ I-TcdB binding was not inhibited by a 100 -fold excess of unlabeled TcdA, and vice versa).

Immunodetection of Rho. Don and T84 cell lysates $(45 \mu \mathrm{g})$ were electrophoresed in $12.5 \%$ SDS-polyacrylamide gels, and proteins were electroblotted onto nitrocellulose filters. After blocking for $1 \mathrm{~h}$ with $2 \%$ BSA in PBS, the filters were probed with 1/100-fold dilution of anti-RhoA antibodies (Santa Cruz Biotechnology, Inc., Santa Cruz, CA). Bound antibodies were detected with a chemiluminescence Western blotting kit (Boehringer Mannheim, Mannheim, Germany) according to the manufacturer's instructions.

\section{Results}

Cytotoxic potencies of TcdA and TcdB on Don and T84 cells. When TcdA and TcdB were titrated on Don cells, TcdB was 1,000-fold more cytotoxic than TcdA (Fig. $1 A$ ). In contrast, on the T84 cells, TcdA turned out to be a 10-fold more potent cytotoxin than TcdB (Fig. $1 B$ ). This difference was due to a 10fold higher sensitivity of T84 cells to TcdA combined with a 1,000-fold lower sensitivity of T84 cells to TcdB compared with Don cells (Fig. 1). The same differences were observed after different time periods from 2 to $24 \mathrm{~h}$ (Table I and Fig. 1).

$T c d B$ is enzymatically more active than TcdA. The UDP- 
A

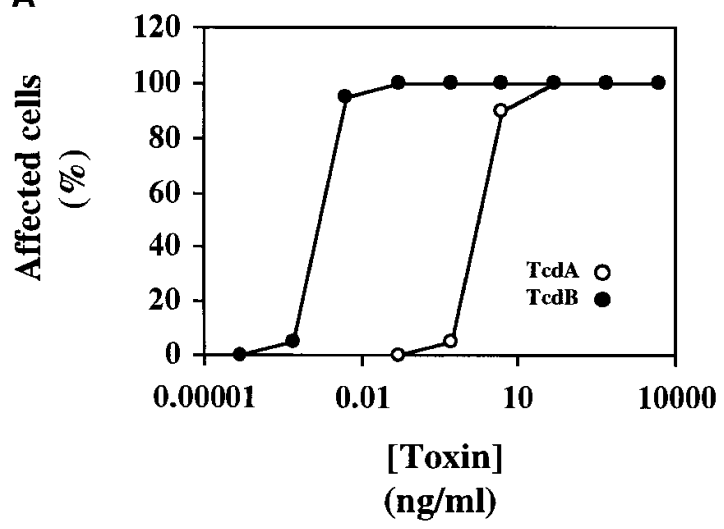

B

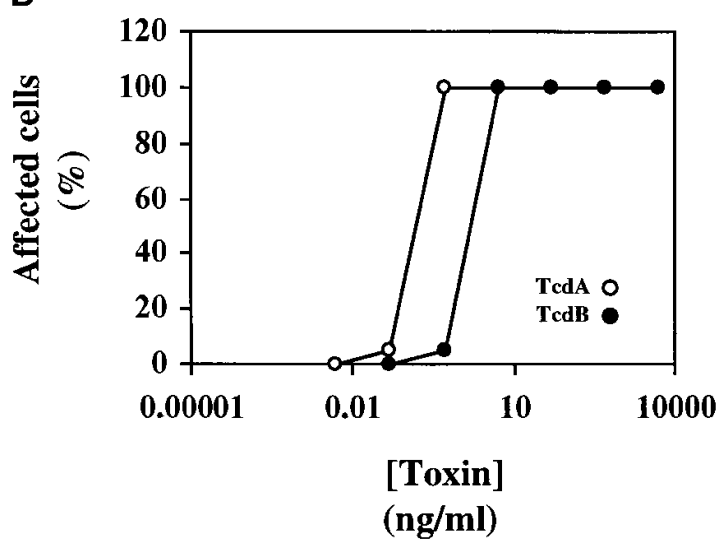

Figure 1. Titration of TcdA and TcdB on Don fibroblasts and T84 cells. Semiconfluent Don fibroblasts $(A)$ or T84 cells $(B)$ growing in 96-well plates were exposed to TcdA (open circles) or TcdB (filled circles) at the indicated concentrations. After $24 \mathrm{~h}$, the percentage of affected cells was scored microscopically.

Glc hydrolase activity of the toxins was determined as a first parameter of enzymatic potency. TcdB was more efficient in hydrolyzing UDP- $\left[{ }^{14} \mathrm{C}\right]$ Glc than TcdA (Fig. 2). The specific hydrolytic activities for TcdA and TcdB were 188 and 1,220 pmol UDP-Glc. $\mathrm{min}^{-1} \cdot \mathrm{mg}$ toxin ${ }^{-1}$, respectively. After $6 \mathrm{~h}, \mathrm{TcdA}(100$ $\mu \mathrm{g} / \mathrm{ml}$ ) had hydrolyzed only $11 \%$ of the available UDP- $\left[{ }^{[4} \mathrm{C}\right] \mathrm{Glc}$, whereas $\mathrm{TcdB}$ at the same concentration had hydrolyzed $73 \%$. Thus, TcdB was clearly more efficient in hydrolyzing UDP-Glc

Table I. TCD ${ }_{25}$ for TcdA and TcdB Applied by Different Routes to Don and T84 Cells

\begin{tabular}{lcccc}
\hline & \multicolumn{2}{c}{ Don cells } & & T84 cells \\
\cline { 2 - 3 } & Extracellular & Microinjected* & Extracellular \\
\hline & $n g / m l$ & $n g / m l$ & $n g / m l$ \\
TcdA & 790 & 500 & 100 \\
TcdB & 0.3 & 5 & 790 \\
\hline
\end{tabular}

TCD causing $25 \% \mathrm{CPE}$ after $2 \mathrm{~h}$ incubation with toxin at $37^{\circ} \mathrm{C}$. * Concentration calculated assuming $1 / 100$ dilution of the microinjected material into the cell. in vitro in the absence of GTPase target. Similar results were obtained at different concentrations of UDP- $\left[{ }^{14} \mathrm{C}\right] \mathrm{Glc}$ (data not shown).

To determine if the difference in hydrolysis of UDP-Glc is reflected in the ability to glucosylate cell substrates, lysates were incubated with different concentrations of the toxins in the presence of UDP- $\left[{ }^{14} \mathrm{C}\right] \mathrm{Glc}$. TcdB was found to be 100 times more potent than TcdA in modifying the substrates in lysates of both Don (Fig. 3, $A$ and $B$ ) and T84 cells (data not shown). The half-maximal modification of substrates in cell lysates occurred with a concentration of $1.5 \mu \mathrm{g} / \mathrm{ml}$ TcdB, whereas a TcdA concentration of $150 \mu \mathrm{g} / \mathrm{ml}$ was required to achieve the same degree of modification (Fig. $3 \mathrm{~B}$ ). To determine if the difference in the ability to modify cell substrates was specific for one or more substrates, recombinant Rho, Rac, and Cdc42 were incubated with the toxins $(100 \mu \mathrm{g} / \mathrm{ml})$ in the presence of UDP- $\left[{ }^{14} \mathrm{C}\right] \mathrm{Glc}$. The signal detected in the three substrates glucosylated by TcdA was only $\sim 5 \%$ of the signal measured in the TcdB-modified substrates (Fig. 4). Thus, TcdA had a lower enzymatic activity also as a glucosyltransferase, and this was not specific for any of the substrates but rather appeared to be a general characteristic of the toxin.

Comparison of lysates from T84 and Don cells. T84 cells were more sensitive to TcdA than to TcdB (Fig. 1 B). However, TcdB was still much more potent as glucosyltransferase than TcdA in T84 cell lysates (compare the controls in Fig. 5, lanes 1 and 3). The possibilities were explored that T84 cells could either $(a)$ contain another cofactor than UDP-Glc which might be used more efficiently by TcdA or $(b)$ have a special profile of small GTPases. To explore $(a)$, T84 cell lysates were treated with TcdA $(100 \mu \mathrm{g} / \mathrm{ml})$ for $1 \mathrm{~h}$ at $37^{\circ} \mathrm{C}$, followed by addition of TcdB $(5 \mu \mathrm{g} / \mathrm{ml})$ and UDP- $\left[{ }^{14} \mathrm{C}\right] \mathrm{Glc}$ and incubation at $37^{\circ} \mathrm{C}$ for another hour. The glucosylation of GTPases with TcdB was decreased only slightly in lysates pretreated with TcdA compared with untreated control lysates (data not shown). This experiment showed that the target amino acid (Thr-35 in

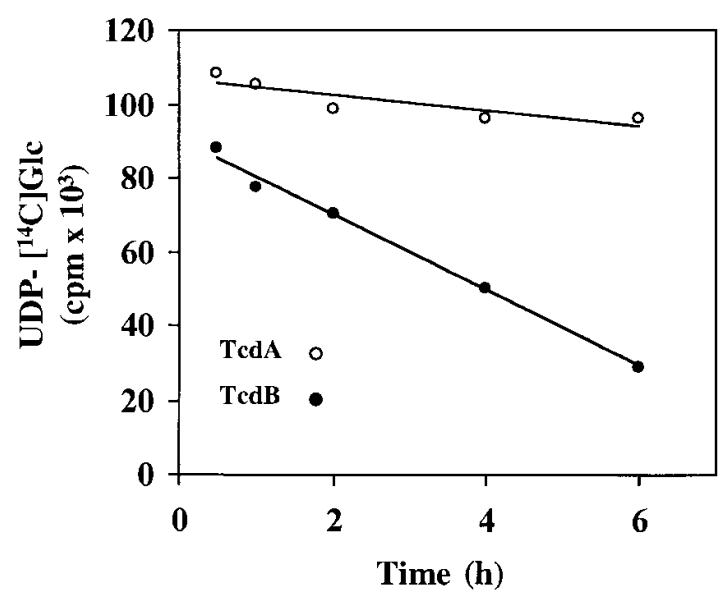

Figure 2. UDP-Glc hydrolase activity of TcdA and TcdB. UDP$\left[{ }^{14} \mathrm{C}\right]$ Glc $(60 \mu \mathrm{M})$ was exposed to $100 \mu \mathrm{g} / \mathrm{ml}$ TcdA (open circles) or TcdB (filled circles) at $37^{\circ} \mathrm{C}$ for the indicated times. After incubation, the reaction was stopped by heating at $95^{\circ} \mathrm{C}$, and the uncleaved UDP$\left[{ }^{14} \mathrm{C}\right]$ Glc was separated from the hydrolysis products by adsorption on activated charcoal. Radioactivity extracted from the charcoal was determined by scintillation counting, and the result was expressed as total counts. This is a representative experiment of three. 
A

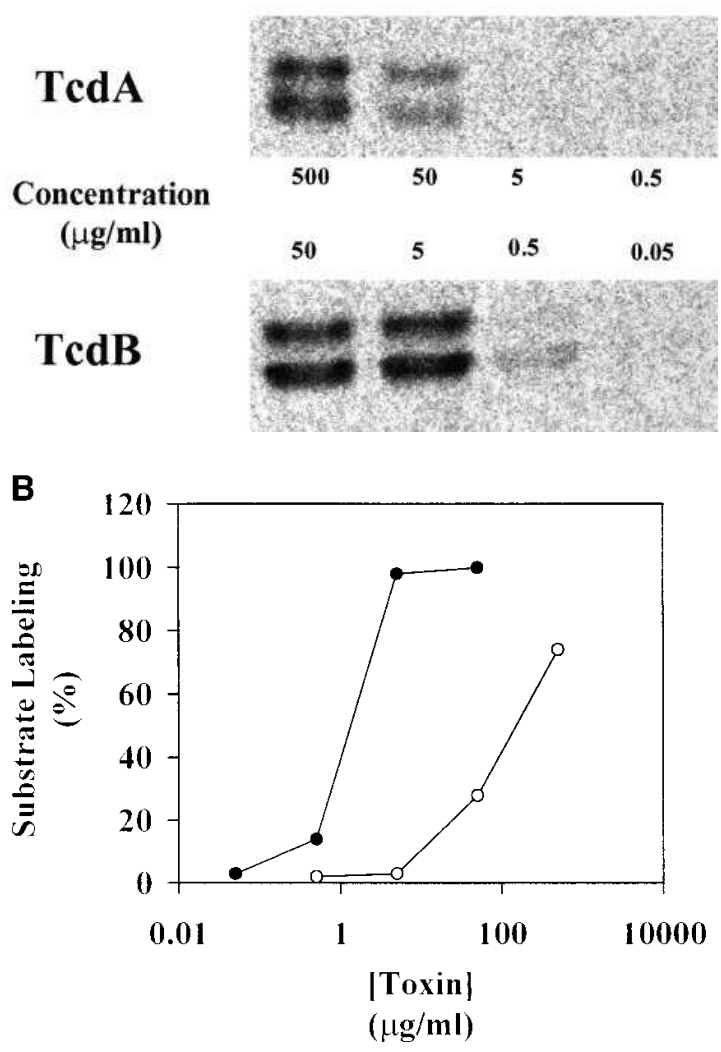

Figure 3. Modification of TcdA and TcdB substrates at different toxin concentrations. $(A)$ Don cell lysates $(50 \mu \mathrm{g})$ were treated for $1 \mathrm{~h}$ at the indicated concentrations of TcdA or TcdB in the presence of UDP- $\left[{ }^{14} \mathrm{C}\right]$ Glc $(30 \mu \mathrm{M})$. After incubation, proteins were resolved by $12.5 \%$ SDS-PAGE, and the gels were analyzed by PhosphorImager. $(B)$ The intensity of the bands in $A$ was quantified using ImageQuant software, and the results were expressed as percentage of the maximun signal obtained with TcdB. Open circles, TcdA. Filled circles, TcdB. This is a representative experiment of three.

Rac and Cdc42, and Thr-37 in Rho) had not been occupied by any other TcdA-transferred glycosyl-moiety. Thus, TcdA did not use any additional glycosyl-cofactor in T84 cells. To explore $(b)$, GTPases were quantified in Don and T84 cells by TcdB-mediated glucosylation or by Western blot. Both cell lysates contained similar amounts of GTPases (data not shown). Thus, the higher cytotoxic activity of TcdA in T84 cells was not due to a different cellular concentration of its substrates.

The possibility that the higher cytotoxicity of TcdA to T84 cells is due to an attack on some other target(s) than Rho, Rac, or Cdc42 was also tested. This was investigated by differential in vivo/in vitro glucosylation (Fig. 5). Intact T84 cells were exposed to either toxin until appearance of $100 \%$ CPE (in vivo treatment). Lysates of the intoxicated cells were then treated with the toxins in the presence of UDP- $\left[{ }^{14} \mathrm{C}\right] \mathrm{Glc}$ (in vitro labeling). In TcdA-pretreated cells, TcdB did not label any additional substrates, indicating that all the targets recognized by TcdB had already been glucosylated by TcdA (Fig. 5, lanes 1 and 2). In contrast, an additional band was labeled by TcdA in lysates from cells pretreated with TcdB (Fig. 5, lanes 3 and 4). The intensity of this band was $35 \%$ of the labeling of the lower

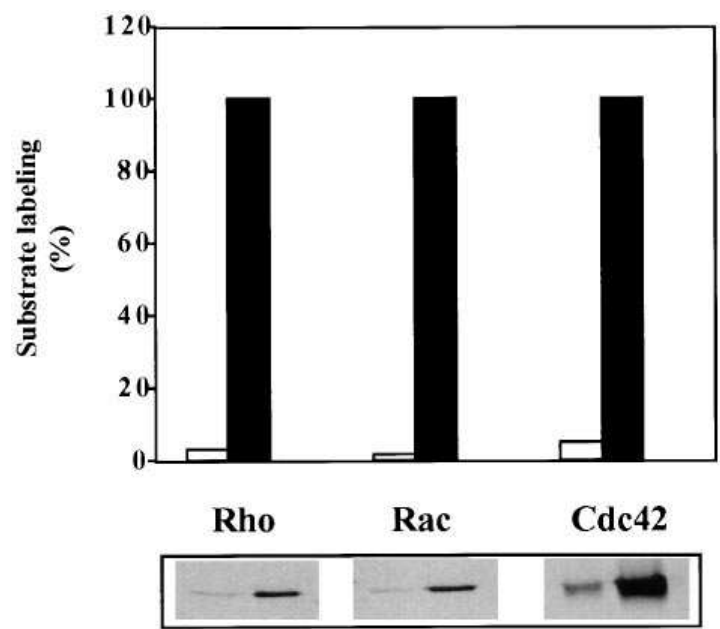

Figure 4. Labeling of recombinant Rho, Rac, and Cdc42 by TcdA and TcdB. Recombinant Rho $(1 \mu \mathrm{g})$, Rac $(1 \mu \mathrm{g})$, and Cdc42 $(3 \mu \mathrm{g})$ were exposed to $100 \mu \mathrm{g} / \mathrm{ml}$ TcdA (white bars) or TcdB (black bars) for $1 \mathrm{~h}$ at $37^{\circ} \mathrm{C}$ in the presence of UDP- $\left[{ }^{14} \mathrm{C}\right] \mathrm{Glc}(30 \mu \mathrm{M})$. After incubation, samples were processed as indicated in Fig. 3. Results were expressed as percentage of the labeling obtained by TcdB. This is a representative experiment of two.

band in the corresponding control (see relative intensities in Fig. 5). Thus, TcdA in T84 cells recognized at least one additional target GTPase which was not affected by TcdB. However, this finding does not explain the higher cytotoxic activity

\section{in vivo TREATMENT}

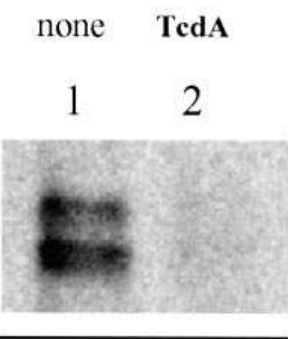

TcdB none TedB

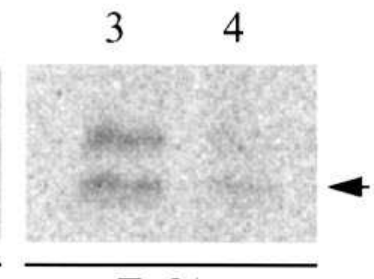

$\operatorname{TcdA}$ in vitro LABELING

\begin{tabular}{|l|l|}
\hline 100 & 5 \\
\hline 100 & 0 \\
\hline
\end{tabular}

\begin{tabular}{|r|r|}
\hline 100 & 6 \\
\hline 100 & 35 \\
\hline
\end{tabular}

\section{Relative intensities (\%)}

Figure 5. Differential in vivo/in vitro glucosylation of small GTPases by TcdA and TcdB. T84 cells growing in $75-\mathrm{cm}^{2}$ flasks were exposed to $500 \mathrm{ng} / \mathrm{ml} \mathrm{TcdA}$ (lane 2) or TcdB (lane 4) until $100 \%$ of the cells were affected (in vivo treatment). Control nontreated cells in lanes 1 and 3. Cell lysates $(50 \mu \mathrm{g})$ were prepared from treated and nontreated cells and incubated for $1 \mathrm{~h}$ at $37^{\circ} \mathrm{C}$ with $100 \mu \mathrm{g} / \mathrm{ml} \mathrm{TcdA}$ (lanes 3 and 4) or TcdB (lanes 1 and 2) in the presence of UDP$\left[{ }^{14} \mathrm{C}\right] \mathrm{Glc}(30 \mu \mathrm{M})$ (in vitro labeling). Samples were then processed as indicated in Fig. 3. The relative intensity of each band in lanes 2 and 4 was reported as percentage of the respective band in lanes 1 and 3 . Arrow, An extra band labeled by TcdA but not by TcdB. This is a representative experiment of two. 
of TcdA in T84 cells, since the same target protein was found to be present also in the Don cells (data not shown).

TcdA glucosylates the small GTP-binding protein Rap. The $C$. difficile toxins have been shown previously not to glucosylate Ras, Rab, or Arf $(6,7)$. Since TcdA was able to glucosylate at least one more substrate than TcdB in cell lysates, we tested toxin-mediated glucosylation of recombinant Rap1 and -2. Interestingly, this Ras-subfamily GTPase was in fact glucosylated by TcdA but not by TcdB at the same concentration (Fig. 6, bottom). Therefore, in evaluating the potency of Rapglucosylation by TcdA, we could not relate TcdA to TcdB. Instead, we compared TcdA with the lethal toxin (TcsL) from $C$. sordellii, which was shown recently to glucosylate Rap (22). Both Rap2 and Rac are glucosylated efficiently by TcsL (Fig. 6). However, the TcdA-induced glucosylation of Rap2 was significantly lower, amounting to $\sim 5 \%$ of that induced by TcsL (Fig. 6). The same results were obtained for Rap1 (data not shown). Thus, Rap-glucosylation by TcdA was equally inefficient as the glucosylation of Rho, Rac, and Cdc42 in comparison with TcdB (Fig. 4). To determine if TcdA-inactivation of Rap proteins is important for the CPE in T84 cells, they were treated with TcsL. However, T84 cells were completely insensitive to the TcsL-induced CPE, although modification of its cellular substrates took place as evidenced by in vivo/in vitro glucosylation (data not shown).

Comparison of cell surface binding and incorporation of radiolabeled toxins in Don and T84 cells. The contribution of the binding and internalization steps to the different cytotoxic potencies of TcdA and TcdB was studied. The degree of association of ${ }^{3} \mathrm{H}$-labeled toxins with Don and T84 cells correlated with their respective cytotoxicities. At $37^{\circ} \mathrm{C}$, Don cells incorporated more TcdB than TcdA, and T84 cells incorporated less TcdB than TcdA (Fig. $7 A$ ). At this temperature, the ra-

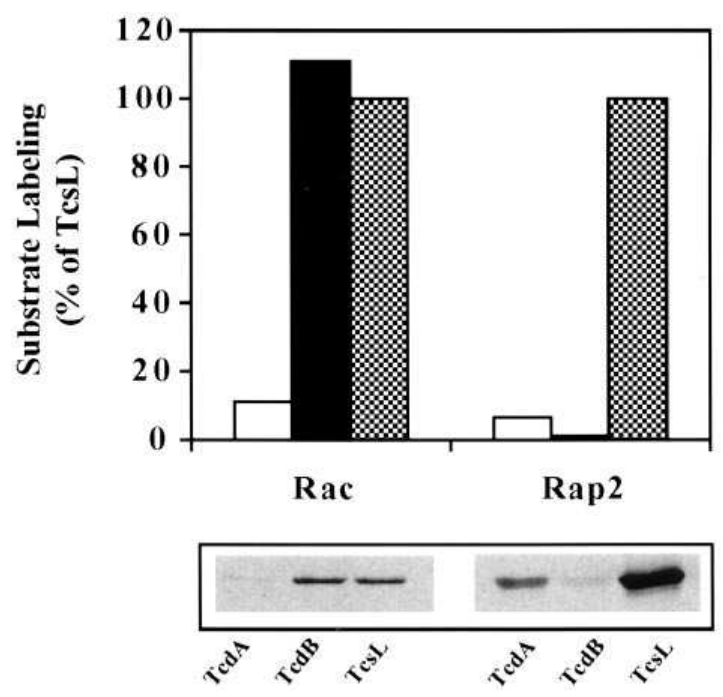

Figure 6. TcdA-mediated glucosylation of Rap2. Recombinant Rac $(1 \mu \mathrm{g})$ or Rap2 $(2 \mu \mathrm{g})$ were incubated with $100 \mu \mathrm{g} / \mathrm{ml}$ of TcdA (white bars), TcdB (black bars), or TcsL (grey bars) in the presence of UDP$\left[{ }^{14} \mathrm{C}\right] \mathrm{Glc}(30 \mu \mathrm{M})$ for $1 \mathrm{~h}$ at $37^{\circ} \mathrm{C}$. After incubation, samples were processed as indicated in Fig. 3. The results were reported as percentage of the signal obtained by TcsL-mediated labeling. This is a representative experiment of two.
A

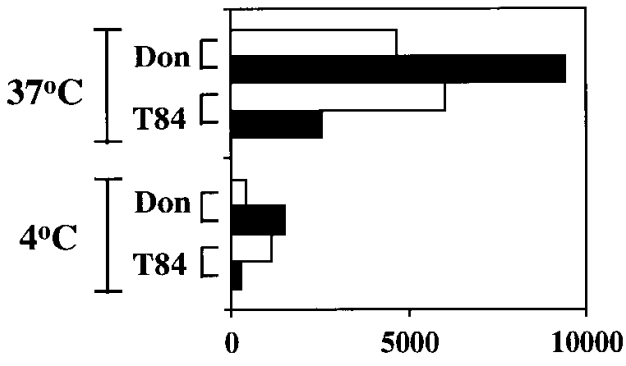

$\mathbf{B}$

Counts/mg cellular protein
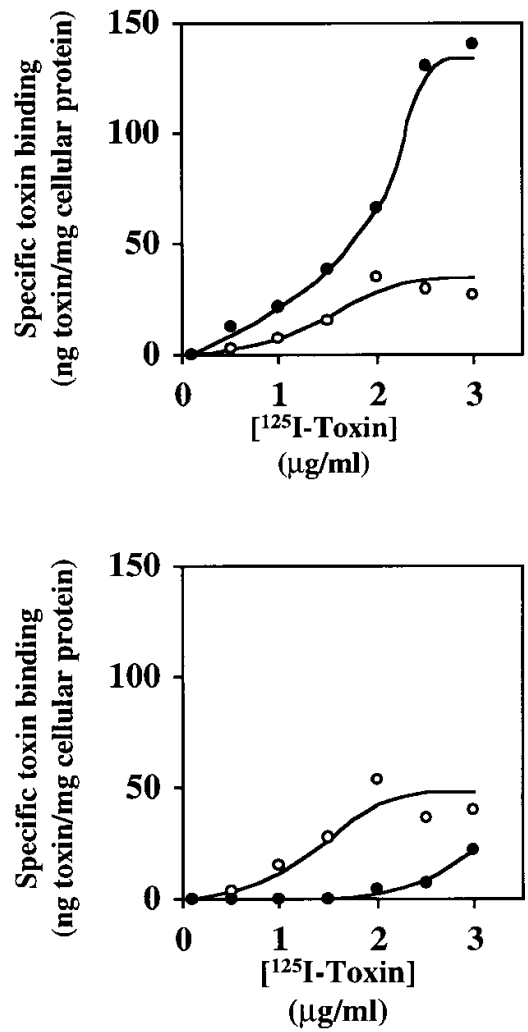

Figure 7. Specific binding and internalization of TcdA and TcdB in Don fibroblasts and T84 cells. ( $A$ ) Confluent Don fibroblasts or T84 cells growing in 24-well plates were exposed to $1 \mu \mathrm{g} / \mathrm{ml}$ of ${ }^{3} \mathrm{H}$-labeled TcdA (white bars) or TcdB (black bars) at 37 or $4^{\circ} \mathrm{C}$ for $2 \mathrm{~h}$. After incubation, nonincorporated toxin was washed away, cells were lysed, and cell-associated radioactivity was determined by scintillation counting. (B) Confluent Don fibroblasts grown in 96-well plates were exposed to the indicated concentrations of ${ }^{125} \mathrm{I}$-TcdA (open symbols) or ${ }^{125} \mathrm{I}$-TcdB (filled symbols) at $4^{\circ} \mathrm{C}$ for $2 \mathrm{~h}$. After incubation, nonbound toxin was washed away, cells were lysed, and total cell-associated radioactivity was determined by gamma counting. Unspecific binding was determined in the same manner, but in the presence of a 100 -fold excess of unlabeled toxin. Specific binding (shown) was calculated by substracting unspecific binding from total binding. $(C)$ The same protocol as for $B$ but using confluent T84 cells. This is a representative experiment of three. Each value represents the mean of duplicate samples.

dioactivity measured corresponded to both bound and internalized toxin. To isolate the binding from the internalization step, the experiment was repeated at $4^{\circ} \mathrm{C}$, and the same differences were seen at this temperature (Fig. $7 A$ ). The binding 
of the toxins to both cell lines was further characterized using ${ }^{125} \mathrm{I}$-TcdA and ${ }^{125} \mathrm{I}-\mathrm{TcdB}$. Binding was found to be specific for both toxins in both Don and T84 cells (Fig. 7, $B$ and $C$ ). Saturation was reached in all cases except for TcdB in T84 cells, suggesting receptors with low affinity for this toxin in these cells. Since toxin internalization is blocked at $4^{\circ} \mathrm{C}(10,11)$, these results suggest that the differential cytotoxicities of the toxins to these two cell types depend partially on differences in the amounts of TcdA and TcdB that the respective cell types can bind specifically. To our knowledge, our data on ${ }^{125} \mathrm{I}-\mathrm{TcdB}$ binding to Don cells are the first to demonstrate a specific and saturable receptor for this toxin.

Cytotoxic potencies of TcdA and TcdB after microinjection into Don fibroblasts. The above results suggested that the generally observed 1000-fold higher cytotoxic activity of TcdB may depend both on its 100-fold higher enzymatic potency and on the difference in receptor-binding abilities. The respective contributions of each of these factors was studied in vivo by microinjecting the toxins directly into the cytosol. By this strategy, the enzymatic modification of the substrates (reflected as the ability to induce a CPE) was isolated from the internalization process.

As in the case of extracellularly applied toxins, TcdB was also more potent than TcdA when microinjected (Fig. $8 A$ ). The difference in cytotoxic potency was quantified by microinjection of different toxin concentrations (Fig. 8 B). TcdB microinjected at $0.5 \mu \mathrm{g} / \mathrm{ml}$ induced a CPE in $\sim 20 \%$ of the cells, whereas with TcdA, a similar response was registered only after microinjection of $50 \mu \mathrm{g} / \mathrm{ml}$ (Fig. $8 \mathrm{~B}$ ). Thus, the difference in cytotoxicity of the microinjected toxins was $\sim 100$-fold (Table I), closely reflecting their differing enzymatic potencies both as UDP-Glc hydrolases and as glucosyltransferases in vitro. This result demonstrates that the enzymatic potency is the main determinant of the 1,000-fold difference in cytotoxicity to Don cells, whereas the differential binding abilities contribute to a lesser degree.

\section{Discussion}

Intracellularly acting toxins generally follow a four-step strategy of intoxication: (a) toxin binding to the cell surface and internalization by endocytosis, $(b)$ intravesicular processing of the toxin followed by translocation of (at least) its catalytic domain across the vesicular membrane, $(c)$ enzymatic modification of an intracellular target(s), and $(d)$ biological consequences of this attack. In this work, we searched for differences in each of these steps of the intoxication process, as induced by the two $C$. difficile toxins. The aim was to clarify why the cytotoxic potencies of TcdA and TcdB differ so much despite their identical molecular mode of action. Don cells were used because of their typical response to the cytotoxic effects of these toxins, being 1,000 times more sensitive to TcdB than to TcdA (Fig. 1 $A$ ). T84 cells were included because they were reported previously to be more sensitive to TcdA than to TcdB when disturbance of barrier function was measured $(23,24)$. In agreement with those reports, we found that TcdA was indeed more active than TcdB on T84 cells also with respect to cytotoxicity (Fig. $1 \mathrm{~B})$; thus, this is the first cultured cell described to be more sensitive to TcdA than to TcdB.

Roles of binding and internalization of TcdA and TcdB. The binding and internalization steps were studied using radiolabeled toxins. The degree of association of TcdA and TcdB with cells at $37^{\circ} \mathrm{C}$ and the specific binding at $4^{\circ} \mathrm{C}$ correlated with their differential cytotoxic activities; i.e., more TcdB was bound specifically to Don cells, while more TcdA was bound specifically to T84 cells (Fig. 7). Thus, the difference in internalization at $37^{\circ} \mathrm{C}$ is likely to depend on a difference in the abilities of the toxins to bind to the cell surface. The demonstrated correlation between specific binding and cytotoxicity pinpoints the binding step as a factor of some importance for the cytotoxic potency of the toxins. This is in agreement with earlier notions (15).

It is not yet known whether large clostridial cytotoxins re-
A
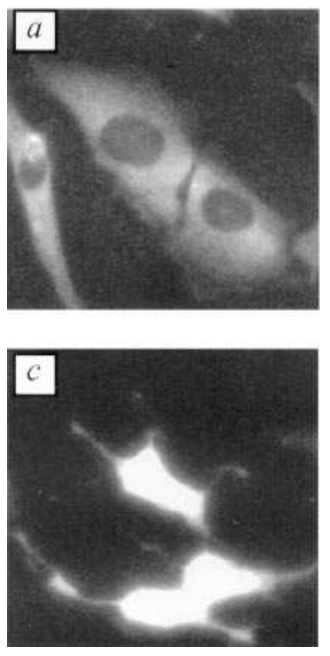
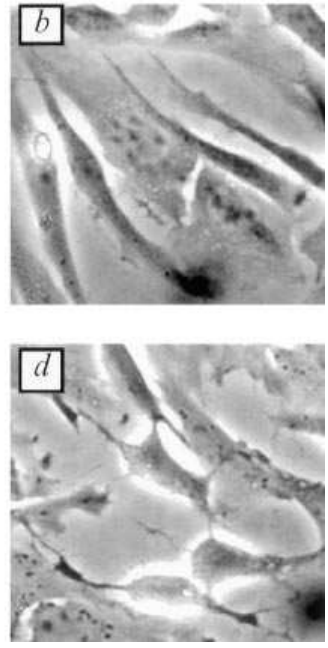

B

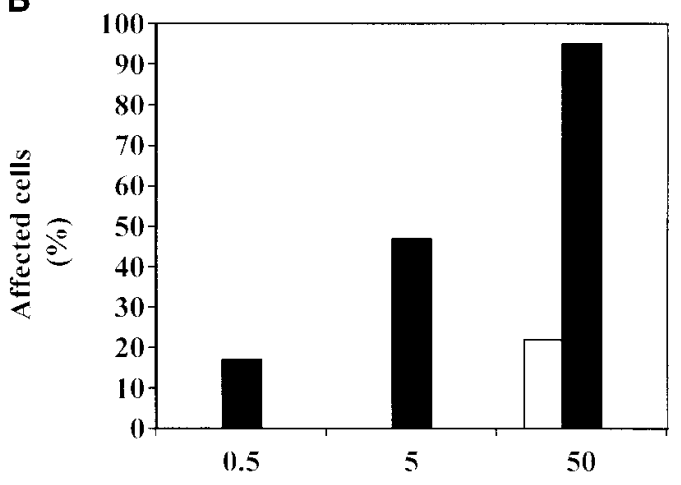

Concentration of Microinjected Toxin $(\mu \mathrm{g} / \mathrm{ml})$
Figure 8. Cytotoxic potencies of TcdA and TcdB upon microinjection. (A) Semiconfluent Don fibroblasts were microinjected with TcdA $(a$ and $b)$ or TcdB ( $c$ and d) at $5 \mu \mathrm{g} / \mathrm{ml}$ diluted in PBS containing $2 \%$ FITC-Dextran. After $2 \mathrm{~h}$ incubation at $37^{\circ} \mathrm{C}$ and fixation in $3.7 \%$ paraformaldehyde, microinjected cells were localized by fluorescence microscopy and photographed in fluorescence $(a$ and $c)$ and phase contrast microscopy $(b$ and d), $\times 400$. (B) Semiconfluent Don fibroblasts

were microinjected with the indicated concentrations of TcdA (white bars) or TcdB (black bars) and incubated for $2 \mathrm{~h}$ at $37^{\circ} \mathrm{C}$. The percentage of affected cells was determined as described in Methods. At least 150 cells were microinjected per experiment, and each experiment was repeated three times. 
quire intravesicular processing in order to reach their site of action, although this has been suggested for TcdB (25). We compared the extracellular and intracellular toxin doses causing the same effect in Don cells in $2 \mathrm{~h}$ (Table I). The results suggest that at least TcdA does not undergo activation on its internalization pathway, since the dose required extracellularly was similar to the dose causing the same effect upon intracellular application (Table I). This implies that any putative processing occurring in the natural intoxication does not significantly promote the TcdA enzymatic activity. On the other hand, there was a 15-fold difference in the tissue culture dose (TCD) ${ }_{25}$ values between microinjected and extracellularly applied TcdB (Table I). This could be due to an ability of the cells to concentrate TcdB in the cytosol (due to vectorial transport of the toxin into the cell) or to an intravesicular activation of TcdB. The first possibility is more likely, since, in fact, TcdB was found to bind and be more efficiently internalized in Don cells than TcdA (Fig. 7). Thus, it seems that if intravesicular processing occurs in order to cleave the catalytic part of the toxins, this might not necessarily increase the enzymatic activity of the toxins. This conclusion is also supported by the fact that $(a)$ provided UDP-Glc is added, both holotoxins are able to modify their recombinant substrates in vitro, i.e., in the absence of cell lysate which should contain any putative activating enzyme, and $(b)$ the recently identified catalytic domain of TcdB (containing the first 546 amino acids) was found to have approximately the same enzymatic activity as the holotoxin, when measured as the ability to glucosylate recombinant Rac1 (26).

Role of enzymatic activity of TcdA and TcdB. The enzymatic activity of TcdA measured as the ability to cleave UDPGlc was lower than that of TcdB (Fig. 2). Also, at the level of in vitro enzymatic attack on the substrates, TcdA was found to be $\sim 100$ times less efficient than TcdB, when measured as the ability to transfer glucose either to the targets in cell lysates or to recombinant targets (Figs. 3 and 4). It is not known which of the steps, the hydrolysis of UDP-Glc or the transfer of the glucose moiety to the substrates, is the rate-limiting step. However, the whole process is 100 times less efficient in TcdA than in $\mathrm{TcdB}$, as evidenced by the in vitro modification of the substrates. The lower enzymatic potency of TcdA seems to be an intrinsic property of the toxin, since it was similarly low towards all the substrates (Figs. 4 and 6). The enzymatic activity of TcdA was also considerably lower than that of the C. sordellii TcsL, which was found to have roughly the same enzymatic potency as TcdB (Fig. 6). Consistent with this, TcsL is equally potent as TcdB upon microinjection and as UDP-Glc hydrolase (Chaves-Olarte, E., and M. Thelestam, manuscript in preparation), although it has a similarly low cytotoxic potency as TcdA when applied extracellularly. For instance, the 24-h $\mathrm{TCD}_{50}$ of TcsL on Don cells was $40 \mathrm{ng} / \mathrm{ml}$ compared with $4 \mathrm{pg} /$ $\mathrm{ml}$ for TcdB (data not shown). Contrasting TcdA, the low cytotoxic potency of TcsL, then, probably depends entirely on an inefficient binding to and uptake in cells. These comparative observations with the three toxins support our conclusion that the main reason for the low cytotoxic potency of TcdA is indeed an intrinsically low enzymatic activity and not just a low capacity for binding to target cells.

Implications of additional substrate for TcdA. The last factor in the intoxication is the modified substrate(s) and the cellular consequences of this modification. It has been reported that TcdA and TcdB modify the same substrates $(6,7)$, which belong exclusively to the Rho subfamily (8). However, we now demonstrate a difference, since TcdA was also able to modify at least two proteins belonging to the Rap subfamily, while TcdB had an extremely weak activity on these substrates (Fig. 6). On the other hand, it is important to note that the enzymatic activity of TcdA towards Rap2 was not stronger than towards its other substrates, e.g., Rac (Fig. 6), reinforcing that the intrinsic enzymatic activity of TcdA is weak. Nevertheless, we considered the possibility that Rap-glucosylation by TcdA might contribute to the higher cytotoxic potency of TcdA on T84 cells. For instance, one could imagine Rap2 to play a crucial role for the morphology of T84 cells but not for fibroblasts. However, this possibility was ruled out by the observation that T84 cells are insensitive to the CPE induced by TcsL, although it efficiently glucosylated Rap (and its other substrates) in intact T84 cells (data not shown). Thus, glucosylation of Rap does not have any relevance for the CPE induced by TcdA in T84 cells. Obviously, this observation does not exclude the possibility that TcdA- (or TcsL-) induced glucosylation of Rap may cause functional disturbances of putative pathophysiological relevance in the absence of morphological alterations. Thus, it should be kept in mind when these toxins are used as tools in studies of cellular signaling, that TcdA glucosylates Rap proteins as well as Rho, Rac, and Cdc42.

Conclusions of this study. Three clear differences were detected in the intoxication processes exerted by TcdA and TcdB. One of them, the modification of additional substrates by TcdA, most probably does not play any role in the different cytotoxic potencies of these toxins, at least in Don and T84 cells (see above). We then clarified the particular contributions of enzymatic activity and cell surface binding, respectively. By microinjecting the toxins directly into the cytosol, the binding and internalization processes were bypassed. Still, the 100-fold difference in enzymatic activity was accurately reflected as a CPE under these in vivo conditions. It is also of interest to note that the cytotoxic titer of TcdB on T84 cells was the same as that of TcdA on Don cells (Fig. 1 and Table I), despite the fact that TcdB bound specifically to T84 cells less efficiently than TcdA bound to Don cells (Fig. 7, $B$ and $C$ ). This implies that more TcdA than TcdB must be taken up to exert the same effect on cells, in agreement with the observed difference in enzymatic activity. Thus, most of the difference in cytotoxic potencies between TcdA and TcdB can be attributed to the difference in their enzymatic activities, while the difference in binding and internalization appears to contribute to a lesser degree.

Roles of TcdA and TcdB in C. difficile infection. One purpose of this kind of study over the long term is to clarify whether the events involved in the cytotoxicity of these toxins are correlated with their pathophysiological effects in the intestine upon $C$. difficile infection. Understanding the molecular mechanism of action on cells should provide important clues about the molecular pathogenesis in vivo. It is intriguing that TcdB alone is not at all enterotoxic $(14,27)$, despite its higher enzymatic and cytotoxic potency. The discrepancy in intestinal activities between TcdA and TcdB has generally been thought to arise simply from a lack (or inaccessibility) of receptors for TcdB on enterocytes (28). The recent elucidation of the identical molecular actions of the toxins evoked the assumption that glucosylation of small GTPases might explain the whole process of $C$. difficile infections $(1,29)$. Our results agree partially with this notion; TcdA was indeed found to bind more efficiently than TcdB to the intestinal T84 cells. 
However, it is important to note that the effects of TcdA and TcdB on T84 cells in terms of cytotoxicity (this study) as well as disturbance of barrier function $(23,24)$ differ only by a factor of 10. This difference per se cannot explain the fact that TcdA in the animal intestine evokes dramatic effects, while TcdB is completely inactive.

The low enzymatic potency of TcdA suggests that glucosylation of small GTPases might not be the primary in vivo effect of this toxin. Interestingly, there are reports of a neuronal involvement in the enterotoxic effects induced by TcdA, suggesting the possibility of another primary action (30). In vivo, the pathophysiological process may be triggered by some kind of transepithelial signal to neuroimmune cells evoked by binding of TcdA to the intestinal mucosa. The cytotoxicity of TcdA and particularly of TcdB via modification of small GTPases could then play a secondary but important role, exacerbating the mucosal inflammation and destruction. This would agree with the strongly potentiating effect of TcdB on sublethal amounts of TcdA, eliciting enterotoxic effects in experimental animals (13). Such a sequence of events would also be consistent with a recent elegant study on isolated strips of human colonic mucosa. Unexpectedly, TcdB in this system was 10 times more potent than TcdA, both with regard to histopathological effects and disturbance of barrier function (31). Thus, TcdB can indeed bind to and damage the actual target mucosa in human C. difficile infections. Since the isolated mucosal strips were devoid of enteric nerves, these observations probably reflect the different enzymatic potencies of TcdA and TcdB that we have clarified here. In conclusion, the data from animal models combined with observations in different kinds of in vitro systems suggest that the primary event in the pathophysiological process may be an activation of the enteric nervous system evoked by TcdA. Whether this is independent of the mild glucosyltransferase activity of this toxin could then be clarified by testing different parts of the toxin molecule on the animal intestine.

\section{Acknowledgments}

The authors are grateful to Alberto Alape Giron and Reini Hurme for critical reading of the manuscript.

This work was supported by the Swedish Medical Research Council (05969), Magnus Bergvalls Stiftelse, Karolinska institutets fonder, Svenska Sällskapet för Medicinsk Forskning, and Deutsche Forschungsgemeinschaft (Ei206 3-2). E. Chaves-Olarte was supported by the Swedish Agency for Research Cooperation with Developing Countries (SAREC).

\section{References}

1. von Eichel-Streiber, C., P. Boquet, M. Sauerborn, and M. Thelestam. 1996. Large clostridial cytotoxins-a family of glycosyltransferases modifying small GTP-binding proteins. Trends Microbiol. 4:375-382.

2. von Eichel-Streiber, C., D. Meyer zu Heringdorf, E. Habermann, and S. Sartingen. 1995. Closing in on the toxic domain through analysis of a variant Clostridium difficile cytotoxin B. Mol. Microbiol. 17:313-321.

3. von Eichel-Streiber, C., R. Laufenberg-Feldmann, S. Sartingen, J. Schulze, and M. Sauerborn. 1992. Comparative sequence analysis of the Clostridium difficile toxins A and B. Mol. Gen. Genet. 233:260-268.

4. Frey, S.M., and T.D. Wilkins. 1992. Localization of two epitopes recognized by monoclonal antibody PCG-4 on Clostridium difficile toxin A. Infect. Immun. 60:2488-2492.

5. Martinez, R.D., and T.D. Wilkins. 1992. Comparison of Clostridium sordellii toxins HT and LT with toxins A and B of C. difficile. J. Med. Microbiol.
$36: 30-36$.

6. Just, I., J. Selzer, M. Wilm, C. von Eichel-Streiber, M. Mann, and K. Aktories. 1995. Glucosylation of Rho proteins by Clostridium difficile toxin B. $\mathrm{Na}$ ture (Lond.). 375:500-503

7. Just, I., M. Wilm, J. Selzer, G. Rex, C. von Eichel-Streiber, M. Mann, and K. Aktories. 1995. The enterotoxin from Clostridium difficile (ToxA) monoglucosylates the Rho proteins. J. Biol. Chem. 270:13932-13936.

8. Aktories, K. 1997. Bacterial toxins that target Rho proteins. J. Clin. Invest. 99:827-829.

9. Aktories, K., and I. Just. 1995. Monoglucosylation of low-molecular-mass GTP-binding Rho proteins by clostridial cytotoxins. Trends Cell Biol. 5:441-443.

10. Florin, I., and M. Thelestam. 1983. Internalization of Clostridium difficile cytotoxin into cultured human lung fibroblasts. Biochim. Biophys. Acta. 763: 383-392.

11. Henriques, B., I. Florin, and M. Thelestam. 1987. Cellular internalisation of Clostridium difficile toxin A. Microb. Pathog. 2:455-463.

12. Teneberg, S., I. Lönnroth, J.F. Torres Lopez, U. Galili, M.O. Halvarsson, J. Ångström, and K.A. Karlsson. 1996. Molecular mimicry in the recognition of glycosphingolipids by Gal $\alpha 3 \mathrm{Gal} \beta 4 \mathrm{GlcNAc} \beta$-binding Clostridium difficile toxin $\mathrm{A}$, human natural anti $\alpha$-galactosyl $\operatorname{IgG}$ and the monoclonal antibody Gal-13: characterization of a binding-active human glycosphingolipid, nonidentical with the animal receptor. Glycobiology. 6:599-609.

13. Lyerly, D.M., K.E. Saum, D.K. MacDonald, and T.D. Wilkins. 1985. Effects of Clostridium difficile toxins given intragastrically to animals. Infect. Immun. 47:349-352.

14. Lyerly, D.M., and T.D. Wilkins. 1995. Clostridium difficile. In Infections of the Gastrointestinal Tract. M.J. Blaser, P.D. Smith, J.I. Ravdin, H.B. Greenberg, and R.L. Guerrant, editors. Raven Press, Ltd., New York. 867-891.

15. Tucker, K.D., P.E. Carrig, and T.D. Wilkins. 1990. Toxin A of Clostridium difficile is a potent cytotoxin. J. Clin. Microbiol. 28:869-871.

16. von Eichel-Streiber, C., U. Harperath, D. Bosse, and U. Hadding. 1987. Purification of two high molecular weight toxins of Clostridium difficile which are antigenically related. Microb. Pathog. 2:307-318.

17. Shoshan, M.C., P. Aman, S. Skog, I. Florin, and M. Thelestam. 1990. Microfilament-disrupting Clostridium difficile toxin B causes multinucleation of transformed cells but does not block capping of membrane Ig. Eur. J. Cell Biol. 53:357-363.

18. Chaves-Olarte, E., I. Florin, P. Boquet, M. Popoff, C. von EichelStreiber, and M. Thelestam. 1996. UDP-glucose deficiency in a mutant cell line protects against glucosyltransferase toxins from Clostridium difficile and Clostridium sordellii. J. Biol. Chem. 271:6925-6932.

19. Hames, B.D. 1976. An improved radiochemical assay for uridine diphosphoglucose pyrophosphorylase. Anal. Biochem. 73:215-219.

20. Laemmli, U.K. 1970. Cleavage of structural proteins during the assembly of the head of bacteriophage T4. Nature (Lond.). 227:680-685.

21. Middlebrook, J.L., R.B. Dorland, and S.H. Leppla. 1978. Association of diphtheria toxin with Vero cells: demonstration of a receptor. J. Biol. Chem. 253:7325-7330.

22. Popoff, M.R., E. Chaves-Olarte, E. Lemichez, C. von Eichel-Streiber, M. Thelestam, P. Chardin, D. Cussac, B. Antonny, P. Chavrier, G. Flatau, et al. 1996. Ras, Rap, and Rac small GTP-binding proteins are targets for Clostridium sordellii lethal toxin glucosylation. J. Biol. Chem. 271:10217-10224.

23. Hecht, G., C. Pothoulakis, J.T. LaMont, and J.L. Madara. 1988. Clostridium difficile toxin A perturbs cytoskeletal structure and tight junction permeability of cultured human intestinal epithelial monolayers. J. Clin. Invest. 82:1516-1524

24. Hecht, G., A. Koutsouris, C. Pothoulakis, J.T. LaMont, and J.L. Madara. 1992. Clostridium difficile toxin B disrupts the barrier function of T84 monolayers. Gastroenterology. 102:416-423.

25. Florin, I., and M. Thelestam. 1986. Lysosomal involvement in cellular intoxication with Clostridium difficile toxin B. Microb. Pathog. 1:373-385.

26. Hofmann, F., C. Busch, U. Prepens, I. Just, and K. Aktories. 1997. Localization of the glucosyltransferase activity of Clostridium difficile toxin B to the N-terminal part of the holotoxin. J. Biol. Chem. 272:11074-11078.

27. Thelestam, M., I. Florin, and E. Chaves-Olarte. 1997. Clostridium difficile toxins. In Bacterial Toxins. K. Aktories, editor. Chapman \& Hall Inc., Weinheim. 141-158.

28. Rolfe, R.D. 1991. Binding kinetics of Clostridium difficile toxins A and $\mathrm{B}$ to intestinal brush border membranes from infant and adult hamsters. Infect. Immun. 59:1223-1230.

29. Wilkins, T.D., and D.M. Lyerly. 1996. Clostridium difficile toxins attack Rho. Trends Microbiol. 4:49-51.

30. Castagliuolo, I., J.T. LaMont, R. Letourneau, C. Kelly, J.C. O'Keane, A. Jaffer, T.C. Theoharides, and C. Pothoulakis. 1994. Neuronal involvement in the intestinal effects of Clostridium difficile toxin A and Vibrio cholerae enterotoxin in rat ileum. Gastroenterology. 107:657-665.

31. Riegler, M., R. Sedivy, C. Pothoulakis, G. Hamilton, J. Zacherl, G. Bischof, E. Cosentini, W. Feil, R. Schiessel, J.T. LaMont, et al. 1995. Clostridium difficile toxin $\mathrm{B}$ is more potent than toxin $\mathrm{A}$ in damaging human colonic epithelium in vitro. J. Clin. Invest. 95:2004-2011. 